\title{
HUBUNGAN ANTARA KESEPIAN DAN MOTIF PERSAHABATAN DENGAN KOMUNIKASI ON LINE PADA \\ REMAJA AKHIR
}

\author{
Agoes Dariyo \\ Fakultas Psikologi Universitas Tarumanagara Jakarta \\ Korespondensi: agoesd@,fpsi.untar.ac.id
}

\begin{abstract}
Abstrak
Tujuan penelitian ini adalah untuk mengetahui hubungan antara kesepian dan motif persahabatan dengan komunikasi on line pada remaja akhir. Alat ukur yang digunakan untuk mengambil data dalam penelitian ini berupa kuesioner yaitu kesepian, motif persahabatan, .dan komunikasi on line. Data yang terkumpul sebanyak 286 orang (86 laki-laki dan 200 wanita) dan dianalisa dengan menggunakan analisa korelasi ganda (multiple correlation) dari spearman. Dalam penelitian ditemukan terdapat hubungan negatif signifikan antara kesepian dengan motif persahabatan $(\mathrm{r}=-0,439$, $\mathrm{p}=0,000<0,01)$; ada hubungan negatif signifikan antara kesepian dengan komunikasi on-line $\quad(\mathrm{r}=-0,154, \mathrm{p}=0,009<0,05)$, dan ada hubungan signifikan antara motif persahabatan dengan komunikasi online ( $\mathrm{r}$ $=0,358, \mathrm{p}=0,00<0,01)$.
\end{abstract}

Kata-kata kunci: kesepian, motif persahabatan, komunikasi on line, remaja akhir.

\begin{abstract}
Aim of this research is to know correlation between loneliness, friendship motive; and on line communication on adolescence. We use questionnaires of loneliness, friendship motive and on line communication, to collect the data. The sum of subjects in this research are 286 adolescences ( 86 men and 200 women ). We analysis data with correlation technique. Found, there are negative correlation between loneliness and friendship motive ( $\mathrm{r}=$ -. $439, \mathrm{p}=.000<.01)$, there are negative correlation between loneliness and on line communication $\quad(r=-.154, p=.009<.05)$, there are correlation between motive friendship and on line communication $(r=.358, p=.000<$ $.01)$.
\end{abstract}

Keywords: loneliness, friendship motive; and on line communication on adolescence. 


\section{PENDAHULUAN}

Komunikasi telah menjadi kebutuhan bagi setiap manusia, sebab manusia adalah makluk sosial yang setiap harinya senantiasa berkomunikasi dengan orang lain. Komunikasi dapat dilakukan setiap saat dengan siapa pun. Komunikasi sebagai upaya untuk menyampaikan suatu pemikiran, sikap, tindakan atau perbuatan kepada orang lain (DeVito, 2013).

Dalam berkomunikasi, seseorang bisa menggunakan media atau sarana elektronik seperti telepon, handphone, internet, facebook atau email (Mesch, 2005; Subrahmanyam and Greenfield, 2008; Destianingrum dan Widiyatmadi, 2011). Dengan sarana tersebut, seseorang semakin mudah untuk berkomunikasi dengan orang lain meskipun jaraknya sangat jauh. Salah satu media komunikasi yang banyak digunakan oleh setiap orang di masa modern ini, adalah komunikasi on line.
Komunikasi on line ialah salah satu cara berkomunikasi yang praktis dan mudah bagi siapa pun. Setiap orang termasuk kelompok remaja bisa melakukan komunikasi on line dengan email, face book, sms, atau sejenisnya (Van den Eijnden, Meerkerk, Vermulst, Spijkerman \& Engel, 2008; Destianingrum, dan Widiyatmadi, 2011).

Bagi kalangan remaja, berkomunikasi on line telah menjadi gaya hidupnya. Mereka merasa familiar dengan cara berkomunikasi on line, sebab mereka berada dalam era perkembangan dan kemajuan teknologi informasi yang sangat mendunia. Di mana pun dan kapan pun, dengan era kemajuan teknologi informasi, maka seseorang merasa terbantu untuk memanfaatkan internet guna menunjang kebutuhan berkomunikasi dengan orang lain (Van den Einjden at al, 2008; Patti M. Valkenburg and Jochen Peter, 2009). Melalui internet, seseorang 
bisa mengakses jutaan informasi dan sekaligus memanfaatkannya untuk berkomunikasi dalam tempo yang cepat. Sebab jaringan komunikasi yang terbangun dalam era teknologi informasi tersebut telah mengalami kemajuan sangat cepat. Sehingga, dalam hitungan detik, seseorang bisa memperoleh berbagai akses informasi serta ia juga bisa berkomunikasi dengan lancar.

\section{Berkomunikasi dengan} orang lain melalui internet, pada dasarnya sebagai ungkapan seseorang dalam memenuhi kebutuhan untuk menjalin hubungan dengan orang lain (Griffin, 1997). Kebutuhan untuk menjalin suatu hubungan dengan orang lain, juga dapat diistilahkan sebagai suatu motif untuk mengembangkan persahabatan (friendship motive) (Ermida, 2001). Bagi remaja yang sedang mengembangkan identitas diri (self-identity), kebutuhan menjalin suatu persahabatan merupakan hal yang cukup penting dalam hidupnya. Mereka hendak mengembangkan ketrampilan sosial (social skill) dalam persahabatan tersebut (Beebe, Beebe \& Redmond, 2005; Papalia, at al, 2011). Karena itu, mereka mudah untuk membuka diri dan menjalin relasi seluasluasnya dengan teman-teman sebaya (peer-group). Dengan persahabatan, remaja juga hendak mencapai kebahagiaan dalam hidupnya sesuai dengan tahap perkembangan yang dijalaninya. Karena itu, ketika remaja mampu mencapai pengembangan persahabatan dengan teman-teman sebaya, maka mereka akan merasakan suatu kebahagiaan dalam hidupnya (Dariyo, 2015).

Cara berkomunikasi melalui internet (atau melalui email) biasa dikenal dengan istilah komunikasi on line. Cara berkomunikasi on line dapat dilakukan oleh setiap orang ketika ia memanfaatkan internet. Sekarang ini akses internet dapat dilakukan dengan berbagai sarana 
seperti computer (PC - personal computer), laptop, I-pad, I-phone, tablet, smart-phone, dan sebagainya. Kemajuan dan perkembangan teknologi informasi sangat terasa untuk mengatasi hambatan bagi kalangan masyarakat luas (Ramdhani, 2011), namun kemajuan teknologi informasi juga dirasakan oleh kaum remaja (Mesch, 2005; Velkenburg, and Peter, 2007). Mereka sebagai remaja dapat merasakan manfaat kemajuan teknologi informasi tersebut, sehingga mereka pun telah mengembangkan gaya hidup berkomunikasi on line. Mereka memiliki ketrampilan dalam memanfaatkan kemajuan teknologi informasi, termasuk bagaimana cara remaja dalam mengakses internet untuk keperluan berkomunikasi on line (Hagie \& Dickson, 2004).

\section{Berkomunikasi on line} sebagai upaya untuk mengatasi rasa kesepian yang dialami oleh remaja. Mereka merasakan kebutuhan untuk mengembangkan suatu persahabatan dengan media komunikasi on line (Van den Eijnden at al, 2007). Kesepian yang dirasakan oleh remaja, mau tak mau harus segera diatasi dengan cara memanfaatkan internet, sehingga mereka pun sering menggunakan internet. Remaja paling tidak menyukai suasana yang sepi, mereka memilih suasana yang membuat mereka merasa bahagia. Hal ini mereka temukan dalam suasana persahabatan dengan orang lain. Dengan demikian, mereka mengatasi kesepian dengan memanfaatkan internet untuk mengembangkan persahabatan. Kesepian teratasi dengan baik, ketika remaja merasakan adanya respon positif orang lain (teman sebaya) yang mau menjalin persahabatan melalui internet.

\section{TINJAUAN PUSTAKA}

\section{Kesepian}

Kesepian ialah perasaan subjektif yang dialami secara individu dalam situasi tertentu. 
Penghayatan masing-masing individu berbeda-beda dalam menyikapi situasi kesepian (Russel, Peplau and Ferguson, 1978; Bausmeister and Vohs, 2007). Bagi orang tertentu kadang merasakan suasana sepi, meskipun ia berada dalam situasi yang ramai bersama dengan orang lain. Namun adakalanya, seseorang tidak merasa sepi, meskipun ia seorang diri tanpa ada kehadiran orang lain. Ia merasa biasa-biasa dan tak merasa sepi, sebab ia mempunyai kesibukan tertentu yang harus dikerjakannya. Ia mencurahkan perhatian dan tenaganya untuk dapat menyelesaikan tugas pekerjaannya. Dalam konteks psikologi social, dikenal dengan kesepian yang bersifat emosional (emotional loneliness) (Russel, Peplau and Cutrona, 1980), dan kesepian social (social loneliness) (Baron \& Byrne, 2004). Kesepian yang tidak teratasi akan menimbulkan kondisi psikoemosional yang tidak baik bagi seorang remaja. Sebab kesepian bisa mengarah pada kondisi depresi (Russel at al, 1978; Yusuf, 2015).

Remaja mudah merasakan kesepian terkait dengan masalah pemanfaatan waktu luang dalam hidupnya. Remaja masih belum mampu mengelola waktunya. Mereka memiliki kesibukan ketika mereka berada dalam lingkungan belajar selama belajar di sekolah (Santrock, 2011). Namun ketika mereka sudah menyelesaikan kegiatan sekolahnya, mereka tak mempunyai kesibukan apa-apa, akibatnya remaja merasa kesepian. Apalagi ketika ia hanya seorang diri, maka perasaan sepi itu sangat dirasakannya. Kondisi ini akan diulang-ulang, jika kondisi remaja tetap tidak menunjukkan perubahan apa-apa dalam hidupnya. Namun ketika remaja sudah beranjak untuk melakukan suatu perubahan dengan mengisi waktu-waktu luang dengan kegiatan-kegiatan 
yang positif dalam hidupnya, maka remaja telah mampu mengatasi kesepian tersebut. Mereka hanya perlu menstabilkan kegiatan tersebut, agar hal itu menjadi gaya hidupnya.

\section{Motif Persahabatan}

Motif persahabatan ialah suatu dorongan seseorang untuk dapat mengembangkan relasi sosial dengan orang lain. Motif persahabatan menggerakkan seseorang untuk aktif membuat persahabatan dengan orang lain (Ermida, 2001). Motif persahabatan juga dianggap sebagai kebutuhan untuk berafiliasi dengan orang lain (Destianingrum, dan Widiyatmadi, 2011). Individu remaja yang mempunyai kecerdasan interpersonal (Rozali, 2015) dan kecerdasan emosional (Dariyo, 2015b) akan mudah dalam mengembangkan suatu persahabatan dengan orang lain. Baik orang yang cerdas secara emosional maupun interpersonal, maka mereka mempunyai sikap keterbukaan. Ia membuka diri terhadap kehadiran orang lain, dalam arti ia bersedia untuk mengenal orang lain dan ia juga mau untuk dikenali oleh orang lain. Kesediaan untuk berkenalan dengan orang lain, merupakan bentuk aktif partisipatif dalam lingkungan sosial. Ia sadar bahwa ia membutuhkan kehadiran orang lain guna mengembangkan potensi dan kompetensinya (Dariyo, 2015b).

Persahabatan telah menjadi bagian penting bagi setiap remaja. Persahabatan menjadi proses belajar sosial yang bermanfaat bagi remaja. Seorang remaja dapat memperoleh pembelajaran yang berarti dan positif dari teman sebayanya (Moller \& Statin, 2001). Dalam persahabatan, seorang remaja bisa bersikap terbuka untuk menerima saran, kritikan atau masukan dari lingkungan sosial. Sikap keterbukaan sesuai dengan karakteristik seorang remaja yang masih dalam tahap pembelajaran 
dalam lingkungan sosial (Papalia at al, 2011).

Sikap keterbukaan
merupakan sikap positif yang
mendorong seseorang untuk
bersedia memperoleh informasi
positif yang berguna bagi
perbaikan dan perkembangan
potensinya (Dariyo, 2015b). Sikap
terbuka menandakan sikap rendah
hati untuk mau belajar dari orang
lain. Jadi remaja benar-benar
merasakan manfaat positif dalam
suatu persahabatan. Gottman dan
Parker (dalam Santrock, 2004)
menyatakan ada 6 dimensi dalam
suatu persahabatan yaitu
companionship, stimulation,
pahysical support, ego support,
social comparison, intimacy dan
affection. Persahabatan
companionship merupakan
pertemanan yang bersifat saling
menguntungkan antara satu
dengan yang lainnya.

\section{Komunikasi On line}

Komunikasi on line ialah

cara seseorang berkomunikasi dengan orang lain yang ditandai dengan memanfaatkan internet (via email) atau media elektronik lainnya (sms atau short message system), bbm (blackberry massanger), whats up dan sebagainya) (Wolak, Mitchell, and Finkelhor, 2003; Mesch, 2005 Van den Eijnden, at al, 2008). Komunikasi on line telah menjadi gaya hidup bagi setiap orang, karena internet telah menjadi kebutuhan hidup untuk dapat melakukan komunikasi dengan orang lain, walaupun komunikasi tersebut mempunyai jarak yang sangat jauh (McKenna \& Bargh, 1998; Wolak at al, 2003; Mesch, 2005).

Komunikasi on line dilakukan oleh mereka yang benar-benar menguasai teknologi informasi. Mereka menyadari bahwa kemajuan teknologi informasi harus dimanfaatkan dengan sebaik-baiknya untuk menunjang komunikasi yang efektif dengan orang lain. Bagi remaja, komunikasi on line dapat dipergunakan untuk 
mengembangkan suatu persahabatan dengan teman sebaya (peer-group) (Wolak at al, 2003; Mesch, 2005; Steirnberg, 2011).

Salah satu kemajuan teknologi informasi yang paling banyak dimanfaatkan oleh masyarakat luas untuk berkomunikasi adalah email, atau facebook dalam internet (Destianingrum,. dan Widiyatmadi, 2011). Dengan email, seseorang bisa menyampaikan pesan dalam waktu yang sangat singkat dan langsung diterima oleh penerima pesan. Tulisan email bisa langsung diterima dan dibaca oleh penerimanya. Namun hasil kiriman via email tersebut bisa dibaca beberapa hari kemudian. Andaikan seorang bisa melakukan chatting yaitu ia bisa berkomunikasi secara langsung dengan penerima pesan. Demikian pula, sebaliknya si penerima pesan bisa langsung membalas dengan mengirimkan pesan kepada teman bicaranya.

\section{PENELITIAN SAAT INI}

Dalam penelitian diajukan hipotesis yaitu ada hubungan antara kesepian dengan berkomunikasi on line, ada hubungan antara kesepian dengan motif persaahabatan, ada hubungan antara motif persahabatan dengan komunikasi on line pada remaja.

\section{METODE}

Karakteristik Subjek. Subjek dalam penelitian ini adalah remaja akhir dengan rentang usia 18-22 tahun. Jumlah subjek laki-laki sebanyak 86 orang $(30,1$ persen) dan subjek wanita sebanyak 200 orang $(69,9$ persen). Adapun dari suku bangsa Jawa (47 orang atau 16, 8 persen), Tionghoa (149 atau 53, 2 persen ), Batak (22 orang atau 7,9 ), Sunda (10 orang atau 3, 2 persen), dan suku lainnya.

Alat ukur penelitian. Alat ukur yang digunakan untuk mengambil data dalam penelitian ini berupa kuesioner yaitu kesepian, motif 
persahabatan, .dan komunikasi on line. Ketiga alat ukur tersebut telah mempunyai standar validitas dan reliabilitasnya. Alat ukur kesepian mempunyai validitas bergerak $(r=.326$ sampai dengan $\mathrm{r}=0,531)$ dan reliabilitas $(\mathrm{a}=$ 0,771); motif persahabatan mempunyai validitas $(r=0,217$ sampai $r=0,576$ ) dan $a=.753$ ); dan komunikasi on line mempunyai validitas $(\mathrm{r}=.241$ sampai dengan $\mathrm{r}=0,597$ dan $\mathrm{a}=$ $0,777)$.

Teknik analisis data. Data yang terkumpul dianalisa dengan menggunakan analisa korelasi ganda (multiple correlation) dari Spearman. Sebelum data diuji dengan korelasi, maka data diuji asumsi yaitu uji linearitas dan normalitas. Kedua uji asumsi tersebut tidak terpenuhi dengan baik. Data Kesepian dengan persahabatan, $\mathrm{p}=0,038<0,05$, artinya distribusi data tidak linear. Kesepian dengan komunikasi on line, $p=0,609>0,05$, artinya distribusi data tergolong linear.

Sementara itu, distribusi data persahabatan tidak normal, sebab hasil uji normalitas diketahui Kolmogorov-Smirnov dengan $\mathrm{p}=$ $0,000<0,05$, demikian distribusi data komunikasi on line diketahui Kolmogorov-smirnov dengan $\mathrm{p}=$ $0,000<0,05$. Dengan tidak terpenuhinya uji asumsi tersebut, maka uji analisa data dengan menggunakan uji non perametrik yaitu korelasi Spearman.

\section{HASIL}

Di bawah ini dikemukakan mengenai hasil analisis data yaitu sebagai berikut:

\begin{tabular}{|c|c|c|c|c|}
\hline & Korelasi & $\mathbf{R}$ & $\mathbf{p}$ & Ket \\
\hline 1 & Kesepian - persahabatan & 0,441 & $0,000<0,01$ & Sign \\
\hline 2 & Kesepian - komunikasi on line & $-0,156$ & $\begin{array}{l}0,008<0 \\
01\end{array}$ & Sign \\
\hline 3 & Persahabatan - komunikasi on line & 0,368 & $\begin{array}{l}0,000<0 \\
01\end{array}$ & Sign \\
\hline
\end{tabular}


Dalam

penelitian

ditemukan terdapat hubungan negatif signifikan antara kesepian dengan motif persahabatan $(\mathrm{r}=$ $0,441, \mathrm{p}=0,000<0,01)$, artinya makin rendah taraf kesepian, makin tinggi motif persahabatan. Sebaliknya, semakin tinggi taraf kesepian, makin rendah pula seseorang mempunyai motif persahabatan.

Selain itu, juga ditemukan ada hubungan negatif signifikan antara kesepian dengan komunikasi on-line $(\mathrm{r}=-0,156, \mathrm{p}$ $=0,009<0,05)$, artinya makin rendah taraf kesepian, maka makin tinggi seseorang untuk melakukan komunikasi on line, sebaliknya makin tinggi taraf kesepian, maka makin rendah komunikasi on line.

Selanjutnya, penelitian ini menemukan bahwa ada hubungan signifikan antara motif persahabatan dengan komunikasi online $(\mathrm{r}=0,358, \mathrm{p}=0,00<$ $0,01)$, artinya makin tinggi motif persahabatan, maka makin tinggi pula seseorang untuk melakukan komunikasi on line. Sebaliknya, makin rendah motif persahabatan, maka makin rendah pula seseorang untuk melakukan komunikasi on line.

Dilihat dari perbedaan jenis kelamin diketahui bahwa rerata empirik kesepian laki-laki ( 24 1395) dan rerata kesepian wanita ( 240151), $\mathrm{F}=.018, \mathrm{p}=0, .893>$ 0,05, arti tidak ada perbedaan kesepian antara remaja laki-laki dengan remaja perempuan.

Mean empirik remaja lakilaki $=50.7093$ dan mean remaja perempuan $=49.7650, \mathrm{~F}=2.121$, $\mathrm{p}=0,146>0,05$, artinya tidak ada perbedaan motif persahabatan antara remaja laki-laki dengan remaja perempuan;

Mean empirik remaja lakilaki $=56.6047$, mean remaja perempuan $=56.7098, \mathrm{~F}=.054, \mathrm{p}$ $=0, .817>0,05$, artinya tidak ada perbedaan komunikasi on line antara remaja laki-laki dengan remaja perempuan. 


\section{PEMBAHASAN}

Dalam pembahasan ini akan dikemukakan bagaimana hubungan antara Kesepian dan Motif Persahabatan, Kesepian dan komunikasi On line, serta Motif Persahabatan dan Komunikasi On line.

\section{Kesepian dan Motif}

\section{Persahabatan}

Dalam penelitian ini ditemukan ada hubungan negatif signifikan antara kesepian dengan motif persahabatan $(r=-0,439$, $\mathrm{p}=0,000<0,01)$, artinya semakin tinggi rasa kesepian yang dialami oleh remaja, maka remaja semakin menyadari akan kebutuhan untuk mengembangkan suatu persahabatan dalam hidupnya. Semakin rendah taraf kesepian yang dialami oleh remaja, maka remaja pun semakin rendah pula dalam upayanya mengembangkan suatu persahabatan. Masa remaja dianggap masa transisi dari masa anak-anak menuju masa dewasa. Masa transisisi yang dialami oleh remaja, mengindikasikan proses perubahan secara menyeluruh meliputi aspek fisik, kognitif, maupun psikososial (Santrock, 2011; Papalia at al, 2011).

Salah satu proses perubahan psikososial yang sedang dialami oleh remaja adalah proses remaja dalam mengembangkan persahabatan (Velkenburg \& Peter, 2007). Remaja tidak hanya menjalin persahabatan dengan sesama jenis kelamin, namun mereka telah memperluas persahabatan dengan lawan jenis (Collin, 2007; Steinberg, 2011). Dalam penelitian ini, ditemukan bahwa tidak ada perbedaan motif persahabatan antara remaja lakilaki dengan wanita. Kedua remaja laki-laki dan wanita sama-sama memiliki motif persahabatan yang cukup baik, artinya mereka mempunyai dorongan untuk memperluas pergaulan dengan teman sebaya.

Di sisi lain, remaja dihadapkan pada suatu kondisi 
yang dilematis, yaitu ia sering merasakan kesepian. Suasana sepi memang tidak mengenakkan bagi seorang remaja. Sebenarnya, remaja ingin menghindari rasa sepi tersebut. Usai dari kegiatan sekolah, remaja memiliki banyak waktu luang, namun ia tidak tahu bagaimana cara untuk mengisinya. Di saat seperti itulah, remaja merasakan kesepian (Papalia at al, 2011).

Rasa kesepian dapat dialami oleh remaja, karena itu remaja merasa terdorong untuk mengatasinya, dengan cara mengembangkan suatu pertemanan dengan usia sebayanya. Kesepian sebagai perasaan emosional yang bersifat subjektif bagi remaja. Mereka menyadari akan kebutuhan kehadiran orang lain dalam upaya mengembangkan suatu persahabatan. Mereka sadar bahwa mereka bukan makhluk individual, namun mereka adalah makhluk sosial. Mereka tidak mungkin hidup seorang diri.
Mereka memerlukan kehadiran orang lain yang dapat memberi dukungan bagi mereka, sehingga mereka percaya diri untuk dapat menumbuh-kembangkan segenap potensinya (Hapasari dan Primastuti, 2014).

\section{Kesepian dan komunikasi On}

line

Ditemukan dalam penelitian ini, bahwa terdapat hubungan antara kesepian dengan komunikasi on line $(r==-0,154$, $p=0,009<0,05)$. Ketika remaja merasa kesepian, maka remaja cenderung melakukan komunikasi on line. Namun ketika remaja tidak merasa kesepian, maka remaja tidak terdorong untuk melakukan komunikasi on line. Remaja paling tidak menyukai kondisi perasaan sepi. Kesepian membuat remaja merasa menderita secara emosional. Ada sesuatu yang harus dipenuhi dalam dirinya, namun kadang remaja tidak tahu bagaimana untuk memenuhi tersebut. Kesepian merupakan suatu 
kondisi emosi yang membuat remaja membutuhkan suatu perhatian, kasih sayang atau kebersamaan dengan orang lain. Karena itu, remaja berusaha sedemikian rupa untuk dapat mengatasi masalah kesepian.

Dengan kemajuan teknologi informasi, maka remaja menemukan cara termudah untuk mengatasi kesepian yaitu dengan mengembangkan ketrampilan berkomunikasi secara on line. Mereka cepat untuk beradaptasi dalam menghadapi perkembangan dan kemajuan teknologi informasi tersebut. Mereka cepat pula menguasai ketrampilan berkomunikasi secara on line (Mesch, 2005; Subrahmanyam and Greenfield, 2008). Berbagai fitur yang ditampilkan dalam internet dapat dipahami dengan baik. Karena itu, rasa sepi yang dialami oleh remaja dapat teratasi dengan baik yaitu dengan cara melakukan komunikasi on line (Subrahmanyam and Greenfield, 2008).
Dilihat dari jenis kelamin ternyata tidak ada perbedaan antara remaja laki-laki dengan remaja wanita dalam merasakan kesepian. Baik remaja laki-laki maupun remaja wanita sama-sama merasakan kesepian. Namun keduanya tidak ditemukan perbedaan taraf kesepian yang dirasakan oleh remaja laki-laki maupun remaja wanita. Demikian pula tidak ada perbedaan remaja wanita maupun remaja laki-laki dalam melakukan komunikasi on line. Keduanya sama-sama memanfaatkan teknologi informasi untuk berkomunikasi on line dengan orang lain atau teman sebaya.

\section{Motif Persahabatan dan}

\section{Komunikasi On line}

Hasil penelitian ini menyatakan bahwa terdapat hubungan positif antara motif persahabatan dengan komunikasi on line $(r=0,358, p=0,00<$ $0,01)$. Remaja menyadari bahwa persahabatan merupakan bagian penting dalam hidupnya, sehingga 
remaja berupaya mengembangkan suatu persahabatan dengan memanfaatkan kemajuan teknologi informasi untuk berkomunikasi. Berkomunikasi sebagai syarat untuk memperat ikatan batin antara seseorang dengan orang lain.

Dengan adanya kemajuan teknologi informasi, maka remaja segera memanfaatkan internet untuk melakukan komunikasi on line dengan teman sebayanya (Velkenburg \& Peter, 2007). Hasil penelitian ini juga mendukung penelitian Destianingrum dan Widiyatmadi (2011) bahwa remaja yang memiliki kebutuhan on line (seperti email, facebook) didasari oleh kebutuhan berafiliasi. Mereka memenuhi kebutuhan berafiliasi dengan cara menggunakan internet untuk berkomunikasi secara on line. Sesuai hasil penelitian Hapasari dan Primastuti (2014) yang menyatakan bahwa dalam persahabatan, seseorang akan memperoleh dukungan sosial dari teman sebaya, sehingga ia semakin merasa percaya diri dalam menghadapi kehidupan di masa yang akan datang. Dukungan social teman sebaya juga bisa diperoleh melalui komunikasi on line.

Cara untuk mengembangkan suatu persahabatan yang dilakukan oleh remaja adalah dengan memanfaatkan kemajuan teknologi informasi (Mesch, 2005). Remaja melakukan komunikasi on line untuk memperluas persahabatan dengan orang lain (Wolak at al, 2003; Velkenburg and Peter, 2007; Subrahmanyam and Greenfield, 2008). Bagaimana pun juga komunikasi dipengaruhi oleh faktor kepribadian (Knapp \& Daly, 2002). Seseorang mau untuk berkomunikasi dengan orang lain, karena ia ingin mengembangkan kepribadiannya. Karena itu, ia mengembangkan sikap keterbukaan. Ia ingin 
mengenal maupun dikenal oleh orang lain (DeVito, 2011).

Orang-orang baru yang dikenal melalui komunikasi on line, merupakan sumber inspirasi bagi remaja. Sebab remaja mempunyai karakteristik yang khas yaitu sifat terbuka. Dengan sifat keterbukaan tersebut, maka mereka mudah untuk menerima ide-ide, gagasan atau pendapat yang baru dari orang lain (Santrock, 2007). Bahkan dengan sikap terbuka pun, seseorang mudah untuk memaafkan orang lain dalam suatu persahabatan, seandainya sahabat telah melakukan suatu kesalahan (Utami, 2015).

Dilihat dari jenis kelamin bahwa tidak ada perbedaan motif persahabatan antara remaja lakilaki maupun remaja wanita. Kedua remaja tersebut sama-sama mempunyai motif persahabatan. Mereka baik remaja laki-laki dan wanita mempunyai dorongan untuk mengembangkan persahabatan dengan orang lain atau teman sebaya.

\section{KESIMPULAN DAN SARAN-}

\section{SARAN}

\section{Kesimpulan}

Terdapat hubungan negatif signifikan antara kesepian dengan motif persahabatan, terdapat hubungan kesepian dengan komunikasi on line, dan terdapat hubungan positif signifikan antara motif persahabatan dengan komunikasi on line.

\section{Saran-saran}

\section{Dengan} adanya pemahaman bahwa kepribadian diduga mempunyai pengaruh terhadap penggunaan komunikasi on line, maka dalam penelitian selanjutnya, dapat disarankan untuk melibatkan variabel lain seperti tipe kepribadian (introvert vs extrovert).

\section{DAFTAR PUSTAKA}

Baron, R.A \& Byrne, D. (2004). Social Psychology. $\left(10^{\text {th }}\right.$ edition). Boston: Allyn and Bacon. 
Bausmeister, R. F and Vohs, K. D. (2007). Encyclopedia of Social Psychology. Los Angeles: A Sage Publications.

Beebe, S.A, Beebe, S.J \& Redmond, M.V. (2005). Interpersonal Communication. $\left(4^{\text {th }}\right.$ edition). Boston: Person.

Collin, N.J. (2007). Adolescence: Continuity, Change and Diversity. Boston: McGraw-Hill.

Dariyo, A. (2015a). Kecerdasan Emosi, Persahabatan dan Kepuasan Hidup Remaja. (Laporan penelitian, tidak diterbitkan) Jakarta: Lembaga Penelitian dan Publikasi Ilmiah Universitas Tarumanagara.

Dariyo, A (2015b). Ketrampilan Organisasi, Kecerdasan Emosi dan Persahabatan. Dalam Prociding Perkembangan Manusia dan Kesejahteraan Psikologis". Malang: Direktorat Program Pascasarjana Universitas Muhammadiyah.

Dariyo, A. (2016). Role of Emotional Intelligence on Chinese Indonesian Adolescence Life Satisfaction. Abstract of The Third International Conference on Chinese Indonesian Studies, March 16-17, 2016.
Daly, J. A., (2002). Personality and Interpersonal Communication, in Knapp, M.L \& Daly, J.A. Handbook of Interpersonal Communication $\quad\left(3^{\text {rd }}\right.$ Edition). London, UK: Sage Publication.

DeVito, J.A. (2011). Interpersonal Messages: Communication and Relationship Skill. Boston: Allyn \& Bacon.

DeVito, J. A. (2013). The Interpersonal Communication Book. Boston: Pearson.

Griffin, E.M. (1997). Communication theory. ( $3^{\text {rd }}$ edition). New York: McGraw-Hill.

Hagie, B \& Dickson, D. (2004). Skilled Interpersonal Communication. $\quad\left(4^{\text {th }}\right.$ edition). New York: Roudledge.

Hapasari, A dan Primastuti, E. (2014). Kepercayaan Diri Mahasiswi Papua Ditinjau dari Dukungan Sosial Teman Sebaya. Psikodimensia, Kajian Ilmiah Psikologi, 13 (1), 60-72.

McKenna, K. Y \& Bargh, J. A. (1998). Coming out in the age of the internet: Identity demarginalization" through virtual group participation. Journal 
personality and social psychology, 75, 681-694.

Mesch, G. (2005). A study of adolescents' online and offline social relationships. Research Report. Oxford Internet Institute. No. 8, 1-24.

Moller, K \& Statin, H. (2001). Are Close relationship in adolescence with partner relationship in midlife ? A Longitudinal perspective study. International Journal Behavior Development, 25 (1), 6977.

Papalia, D.E, Olds, S.W \& Feldman, R.D. (2011). Human Development. (eleventh edition). Boston: McGraw-Hill.

Destianingrum, E. dan Widiyatmadi, E (2011). Perilaku Penggunaan Jejaring Sosial Facebook pada mahasiswa Ditinjau dari Kebutuhan Afiliasi. Psikodimensia, Kajian Ilmiah Psikologi, 10 (1), 82-93.

Ramdhani, N. (2011). Kajian Psikologis Mengenai Komunikasi Berbasis Paperless Office. Jurnal Psikologi Fakultas Psikologi Universitas Gadjah Mada, 38 (2), 115-133.

Rozali,Y, A. ( 2015). Kecerdasan Interpersonal Ditinjau dari Penerapan Pola Asuh Orangtua. Dalam
Prociding

Perkembangan Manusia dan Kesejahteraan Psikologis". Malang: Direktorat Program Pascasarjana Universitas Muhammadiyah.

Russel, D., Peplau, L. A., and Ferguson, M. L. (1978). Developing a Measure of Loneliness. Journal of Personality Assesment, 42 (3), 290-294.

Russel, D., Peplau, L. A., and Cutrona, C. E. (1980). The Revised UCLA Lonelines Scale: Concurent and Discriminan Validity Evidence. Journal of Personality and Social Psychology, 39 (3), 472480.

Santrock, J.W. (2007). Adolescence. Boston: McGraw-Hill.

Steinberg, L. (2011). Adolescence. $\quad\left(10^{\text {th }}\right.$ edition). New York: McGraw-Hill.

Subrahmanyam, K and Greenfield, P. (2008) Communicating Online: Adolescent Relationships and the Media. Future of Children, 18 (1), 1-27.

Utami, D. A. (2015). Kepercayaan Interpersonal dengan Pemaafan dalam Hubungan Persahabatan. Jurnal Ilmiah Psikologi Terapan, 3 (1), 54-70. 
Van den Eijnden, R.J.J.M, Meerkerk, G.J, Vermulst, A.A, Spijkerman, R \& Engel, R.C. M.E (2008). Online Communication, compulsive Internet Use, and Psychological Well Being among adolescence: A Longitudinal Study. Development Psychology, 44 (3), 655-665.

Velkenburg, P. M \& Peter, J. (2007). Preadolescence and Adolescence' Online Communcation and Their Closeness to Friends. Developmental Psychology, 43, -267-277.

Valkenburg, P.M. and Peter, J. (2009). Social Consequences of the Internet for Adolescents: A Decade of Research. Current Directions in Psychological Science. 118.

Wolak, J Mitchell, K.J. and Finkelhor, D. (2003). Escaping or connecting? Characteristics of youth who form close online relationships. Journal of Adolescence, 26, 105-119.

Yusuf, N. F. (2015). Pengaruh Kesepian terhadap Depresi pada Remaja. Dalam Prociding " Perkembangan Manusia dan Kesejahteraan Psikologis". Malang: Direktorat Program Pascasarjana Universitas Muhammadiyah.

\section{UCAPAN TERIMAKASIH}

Peneliti mengucapkan rasa terimakasih atas dukungan dana yang diberikan oleh Lembaga Penelitian dan Publikasi Ilmiah Universitas Tarumanagara (LPPI Untar) Jakarta, sehingga kegiatan penelitian ini dapat terselesaikan dengan baik 